\title{
Protective Effects of Moringa oleifera extract on Isoniazid and Rifampicin Induced Hepatotoxicity in Rats: Involvement of Adiponectin and Tumor Necrosis Factor- $\alpha$
}

\author{
Abeer A. A. Salama*, Abdel-Hameed M. Fayed",Taha A. Attia**, Elbatran Seham

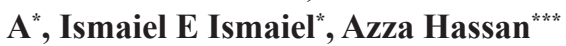 \\ *Pharmacology Department National Research Centre, **Pharmacology Department, \\ Faculty of Vet. Med., El-Sadat University, Minoufya,***Pathology Department, \\ Faculty of Vet. Med., Cairo University, Giza, Egypt.
}

\begin{abstract}
$\mathbf{H}$ EPATOTOXICITY is the major health problem that is a global concern worldwide especially in Egypt because the liver injury is one of the most ten disease leading to death. There are many factors leading to hepatotoxicity as antibiotics like Isoniazid (INH) and rifampicin (RIF) which are the first line remedies in treatment of tuberculosis. The present study evaluates the possible hepatoprotective effects of Moringa oleifera against the experimentally induced hepatotoxicity with INH/RFP in rats. Forty eight rats $(200-250 \mathrm{~g})$ were allocated into six groups (8 rats in each group), and treated as follow: group I: received normal saline orally, group II: received INH/ RIF (50 mg/Kg/day of each)for 28 days orally, group III: received Silymarin $(50 \mathrm{mg} / \mathrm{kg} /$ day $)+\mathrm{INH} / \mathrm{RIF}$ for 28 days orally, group IV, V, VI: received Moringa oleifera ethanolic extract (MOEE) $(250,500$ and $1000 \mathrm{mg} / \mathrm{Kg} /$ day $)+\mathrm{INH} / \mathrm{RIF}$ for 28 days respectively. Co-administration of Moringa oleifera with INH/ RIF reduced elevated serum alanine aminotransferase (ALT), aspartate aminotransferase (AST), alkaline phosphatase (ALP) and (bilirubin total \&direct) levels but also decreased the elevated malondialdehyde (MDA) $\&$ tumor necrosis factor- $\alpha$ (TNF- $\alpha$ ) contents in liver homogenate. Moreover, administration of Moringa oleifera increased glutathione peroxidase (GPX) \& adiponectin activity. Microscopic examination of Moringa olifera extract administration revealed reduction in the severity of liver damage. It is concluded that Moringa olifera might be considered as adjuvant drug in treatment of liver disorder and or as hepatoprotective therapy with anti-tubercular drugs.
\end{abstract}

Keywords: Moringa olifera, Hepatotoxicity, Isoniazid and Rifampicin, Adiponectin. Tumor Necrosis Factor- $\alpha$

\section{Introduction}

Liver disease has become a global concern worldwide [1]. Liver injury (liver dysfunction) is a principal health problem that oppose not only health care professionals but also the pharmaceutical industry and drug regulatory agencies [2]. Hepatotoxicity is a hepatic cells damage resulting from liver toxicity. That induced by exposure to a drug or another agent [3].

Isoniazide (INH) and rifampicin (RIF) are the first line remedies in treatment of tuberculosis. They are associated with hepatotoxicity [4].
In the administration of RIF plus INH as combination therapy, RFP shortened the time required for the INH metabolites to reach hepatotoxic levels, where this combination possess synergistic rather than additive hepatotoxic effect [5]. RFP, considered as a powerful inducer of mixed-function oxidase [6]. The major mechanism by which INH and RFP hepatotoxicity occurred is endogenous lipids peroxidation[7]. This lipid peroxidation initiated by two mechanisms. First, formation of highly reactive oxygen species (ROS), which consequently destruct and damage the cell membrane [8]. Second,

Corresponding Author: E-mail: fayed.nrc@gmail.com DOI: 10.21608/EJVS.2018.2349.1025 
reduction in glutathione level (which responsible for removing the majority of normally formed free radicals) resulting in tissue injury [9]. In addition inflammation and fibrosis are involved in hepatotoxicity, regulated by adiponectin [10].

Adiponectin is a prototypic adipocytokine [11], the actions of which are mainly exerted by the activation of AMP-activated kinase and peroxisome proliferator-activated receptor alpha. This adipocytokine is one of the most abundant circulating (adipo) cytokines in health. Adiponectin has many anti-inflammatory activities and suppresses tumour necrosis factoralpha (TNF) so the protective role of adiponectin against liver injury is partly due to its antagonistic effect against TNF- $\alpha$ in its circulating form or its expression in adipose tissue [12]. The antiinflammatory effects of adiponectin are also exerted by induction of the anti-inflammatory cytokines interleukin-10(IL-10) [13]

Due to the absence of a reliable liver protective drug in the modern medicine, some scientists and patients resort to herbs in the management of various liver disorders [14]. It is imperious to present alternative remedies for the treatment of liver disease of confirmed efficacy and safety [15].

Moringa oleifera, known as drumstick tree, one member of the Moringaceae family which characterized by the most closely cultivated species of Moringaceae family, this tree was widely distributed as domestic to the sub-Himalayan tracts of east Asian countries especially India, Pakistan, Bangladesh and Afghanistan [16, 17]. Moringa oleifera leaves possess various biological activities, especially in prevention of cardiovascular diseases [18, 19], hypotensive and immune boosting agent [20], diuretic, cholesterol lowering, and antiulcer properties [21], antioxidant activity [22]. This antioxidant properties are involved in protection of the liver tissue against hepatotoxin-induced toxicity $[23,24]$.

\section{Material And Methods}

\section{Plant}

Moringa oleifera whole plants were obtained from Agriculture faculty; Cairo University. The plants and its leaves were identified and authenticated as plants of Moringa oleifera by the taxonomy section of the Department of Biological Sciences, Cairo University, Egypt.

\section{Preparation of Alcoholic Extract}

These extracts were obtained by the following steps: Grinding Moringa oleifera leaves in blender till obtain powder, maceration with petroleum ether to remove fatty substances and the marc was further exhaustively extracted with $70 \%$ ethanol for 3 days ( 3 X 5L), Soaking this powder in ethyl alcohol for seven days with rotation every day, Filtration by using piece of cotton, separation by filtration and concentration on rotavapour (Buchi, USA) and then during in lyophilizer (Labconco, USA) under reduced pressure, repeat extraction by using the fine particles of sediment to resoak in ethyl alcohol and repeat several times till obtaining clear supernatant then this extract will be stored in an airtight container in a refrigerator below $10{ }^{\circ} \mathrm{C}$.

\section{Drug}

INH/RFP was purchased from Sandoz $\mathrm{GmbH}$, Biochemiestrasse, Austria. Silymarin was purchased from Novartis Pharma, Cairo, Egypt.

\section{Animals}

Forty eight adult male Wistar albino rats, weighing between 200-250 g were obtained from the animal house colony, National Research Centre, Giza, Egypt. All animals were kept in metal cages at animal house of National Research Centre under standard conditions. Food and water was available to the rats. All experiments were carried out according to the ethical guidelines for care and use of experimental animals approved by the Ethical Committee of the National Research Centre.

\section{Experimental design}

Animals were randomly divided into six groups, each of eight animals. Group I: Normal control received $1 \mathrm{ml}$ saline daily for 28 days, orally, Group II: Positive control group received daily oral doses of INH-RIF $50 \mathrm{mg} / \mathrm{kg}$ of each for 28 days to induce hepatic injury [25], Group III: the Reference group, received silymarin daily oral dose $(50 \mathrm{mg} / \mathrm{Kg})$ in concurrent with INH and RFP, for 28 days [26]. Groups: IV, V and VI Moringa oleifera groups (animals in this groups were given three different oral doses 250, 500 and $1000 \mathrm{mg}$ MOEE $/ \mathrm{kg}$ in concurrent with INH and RFP, for 28 days [27].

\section{Blood collection and tissue preparation}

blood samples were collected from the retroorbital venous plexus of rats under light ether anesthesia and collected in clean test tubes, allowed to clot, then centrifuged for 10 minutes 
at 3000 r.p.m. Serum was separated and stored into Eppendorff tubes at $-20{ }^{\circ} \mathrm{C}$ to be used for determination of liver function parameters. After collection of blood samples, rats were killed by cervical dislocation and their livers were immediately removed. Moreover, livers of rats were divided into 2 parts, the first liver samples were kept at $\left(-80{ }^{\circ} \mathrm{C}\right)$ for determination of hepatic contents of Malondialdehyde (MDA), glutathione peroxidase (GPx), tumor necrosis factor-alpha (TNF- $\alpha$ ) and adiponectin. The second liver samples were preserved in phosphate buffered formalin $10 \%$ for further histopathological investigation.

Biochemical analysis of serum samples.

AST and ALT were determined using Reitman and Frankel [28] methods. Alkaline Phosphate (ALP) was determined as outlined by Beifield and Goldberg [29], total and direct bilirubin were determined according to Walter and Gerade [30], using Biodiagnostic kits, Egypt. MDA was estimated as described by Ohkawa et al. [31], GPx defense according to the colorimetric method of Paglia and Valentine [32] Determination of TNF- $\alpha$ were quantified as performed by Pennica et al. [33] and adiponectin as performed by Kojima et al. [34]

\section{Liver histopathological assessment}

For histopathological studies, few-millimeters mid-sections of the left lobes, of the livers excised from each group were processed for light microscopy. The processing involved fixing the tissue specimens in a 10\% neutral buffered formalin solution, preparing the blocks in paraffin, cutting sections 5-6 $\mu \mathrm{m}$ in thickness, and staining the sections with haematoxylin-eosin stain. The sections were scanned and analyzed by an expert pathologist who was not aware of sample assignment to experimental groups [35].

\section{Statistical analysis}

In the present study, all results were expressed as mean \pm standard error of the mean. Data analysis was achieved by one-way analysis of variance (ANOVA) followed by LST comparison test using software program GraphPad Prism (version 5.00). Difference was considered significant when $\mathrm{P}<0.05$.

\section{Results}

Effects of Moringa oleifera extract and silymarin on levels of serum liver enzymes:

The present results revealed that induction of hepatotoxicity by RFP/INH elevated serum levels of ALT, AST, ALP, total and direct bilirubin by $36,14,101,48 \& 82 \%$ respectively, as compared to normal control group. Silymarin treatment significantly reduced liver enzymes levels as ALT, AST, ALP, total and direct bilirubin by
$22,12,100,8$ and $81 \%$ respectively, as compared with RFP/INH toxicated groups. Moringa oleifera $250 \mathrm{mg} / \mathrm{kg}$ treatment significantly reduced serum levels of ALT, AST, ALP, total and direct bilirubin by $19,9,92,30$ and $64 \%$ respectively, Moringa oleifera $(500 \mathrm{mg} / \mathrm{kg})$ treatment significantly reduced serum levels of ALT, AST, ALP, total and direct bilirubin by $21,11,100,45$ and 66 $\%$ respectively, Moringa oleifera $(1000 \mathrm{mg} / \mathrm{kg})$ treatment significantly reduced serum levels of ALT, AST, ALP, total and direct bilirubin by 24 , $14,101,48$ and $67 \%$ respectively, as compared with RFP/INH toxicated groups (Table 1).

Effects of Moringa oleifera extract and silymarin on liver content of MDA and GPX contents:

The present biochemical results revealed that induction of hepatotoxicity by RFP/INH elevated liver content of MDA and GPx by 39 and 93 $\%$ respectively, as compared to normal control group. Silymarin treatment significantly reduced liver content of MDA and GPx by 29 and 44\% respectively, as compared with RFP/INH toxicated groups. Moringa oleifera $(250 \mathrm{mg} / \mathrm{kg})$ treatment significantly reduced liver content of MDA and GPx by 27 and $47 \%$ respectively, Moring a oleifera $500 \mathrm{mg} /$ $\mathrm{kg}$ treatment significantly reduced liver content of MDA and GPx by 49 and 50\% respectively, Moringa oleifera $1000 \mathrm{mg} / \mathrm{kg}$ treatment significantly reduced liver content of MDA and GPx by 50 and $88 \%$ respectively, as compared with RFP/INH toxicated groups (figure 1,2).

Effects of Moringa oleifera extract and silymarin on liver content of TNF-content:

The present biochemical results revealed that induction of hepatotoxicity by RFP/INH elevated liver content of TNF- $\alpha$ by $886 \%$, as compared to normal control group. Silymarin treatment significantly reduced liver content of TNF- $\alpha$ by $67 \%$, as compared with RFP/INH toxicated groups. Moringa oleifera $(250,500$ and $1000 \mathrm{mg} / \mathrm{kg})$ treatment significantly reduced liver content of TNF- $\alpha$ by $(140,145$ and $237 \%$ ) respectively, as compared with RFP/INH toxicated groups (figure 3).

Effects of Moringa oleifera extract and silymarin on liver content of adiponectin

The present biochemical results revealed that induction of hepatotoxicity by RFP/INH $50 \mathrm{mg} /$ $\mathrm{kg}$ of each elevated liver content of adiponectin by $20 \%$ as compared to normal control group. Silymarin treatment significantly reduced liver content of adiponectin by $15 \%$, as compared with RFP/INH toxicated groups. Moringa oleifera 250,500 and $1000 \mathrm{mg} / \mathrm{kg}$ treatment significantly reduced liver content of adiponectin by $(15,17$ and $322 \%$ ) respectively as compared with RFP/ INH toxicated groups (figure 4).

Egypt. J. Vet. Sci. Vol. 49. No, 1 (2018) 
TABLE 1. Effects of Moringa oleifera extract and silymarin on serum liver enzymes.

\begin{tabular}{|c|c|c|c|c|c|c|}
\hline & $\begin{array}{l}\text { Normal } \\
\text { control } \\
\text { (Saline) }\end{array}$ & RIF/INH & $\begin{array}{c}\text { Silymarine(50 } \\
\text { mg/kg bwt) }\end{array}$ & $\begin{array}{l}\text { Moringa olifera } \\
\qquad(250 \mathrm{mg} / \mathrm{kg})\end{array}$ & $\begin{array}{l}\text { Moringa olifera } \\
(500 \mathrm{mg} / \mathrm{kg})\end{array}$ & $\begin{array}{l}\text { Moringa olifera } \\
(1000 \mathrm{mg} / \mathrm{kg})\end{array}$ \\
\hline Alanine transferase & $182.60 \pm 9.44$ & $248.89 \pm 10.32^{\text {a }}$ & $208.73 \pm 5.63^{a b}$ & $214.72 \pm 1.30^{\mathrm{ab}}$ & $211.29 \pm 1.92^{\mathrm{ab}}$ & $204.81 \pm 4.53 \mathrm{ab}$ \\
\hline Aspartatetransferase & $157.71 \pm 1.83$ & $179.87 \pm 1.09^{\mathrm{a}}$ & $160.54 \pm 5.96^{b}$ & $165.52 \pm 1.70^{\mathrm{b}}$ & $162.99 \pm 2.97^{\mathrm{b}}$ & $157.80 \pm 2.27^{\mathrm{b}}$ \\
\hline $\begin{array}{l}\text { Alkaline } \\
\text { phosphatase }\end{array}$ & $55.83 \pm 3.91$ & $112.16 \pm 6.18^{\mathrm{a}}$ & $56.51 \pm 0.97^{\mathrm{b}}$ & $60.88 \pm 2.91^{\mathrm{b}}$ & $56.18 \pm 1.42^{b}$ & $55.57 \pm 2.90^{\mathrm{b}}$ \\
\hline Bilirubin total & $2.99 \pm 0.17$ & $4.44 \pm 0.19^{\mathrm{a}}$ & $4.19 \pm 0.07^{\mathrm{b}}$ & $3.53 \pm 0.11$ ab & $3.08 \pm 0.17$ b & $3.01 \pm 0.25^{\mathrm{b}}$ \\
\hline Bilirubin direct & $1.76 \pm 0.08$ & $3.22 \pm 0.30^{\mathrm{a}}$ & $1.79 \pm 0.12^{b}$ & $2.10 \pm 0.07^{\mathrm{b}}$ & $2.06 \pm 0.02^{b}$ & $2.04 \pm 0.16^{\mathrm{b}}$ \\
\hline
\end{tabular}

.(Data were expressed as mean $\pm \mathrm{SE}(\mathrm{n}=6$

.Statistical analysis was carried out by one-way ANOVA followed by LSD test

a Significantly different from normal control at $\mathrm{P}<0.05$

b Significantly different from RIF/INHat $\mathrm{P}<0.05$

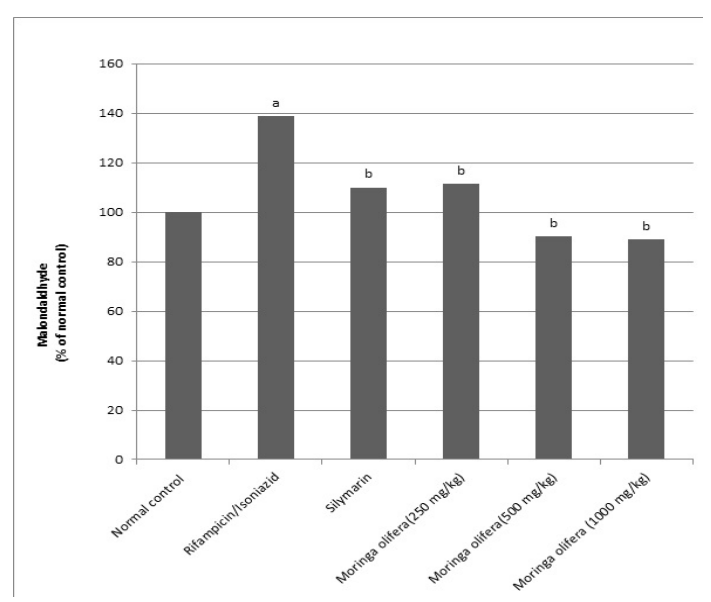

Fig. 1. Effects of Moringa oleifera extract and silymarin on Malondaldhyde (MDA).

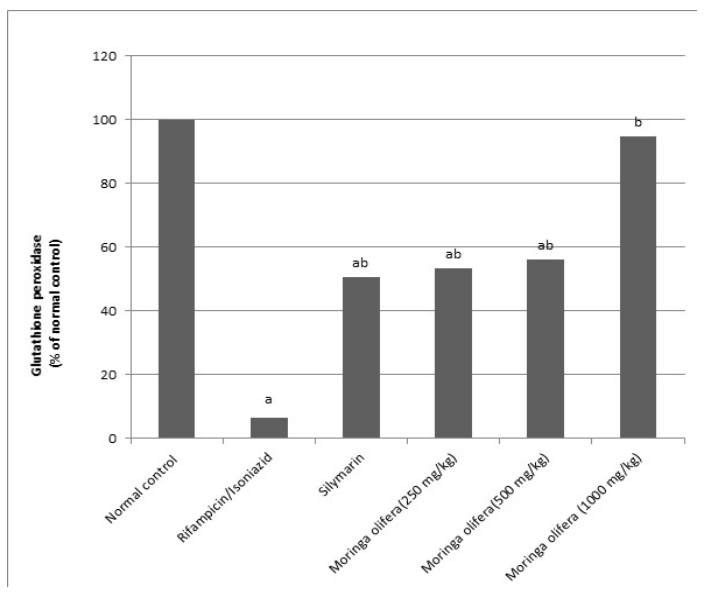

Fig. 2. Effects of Moringa oleifera extract and silymarin on Glutatione peroxidase content (GPx).

Egypt. J. Vet. Sci. Vol. 49. No, 1 (2018)

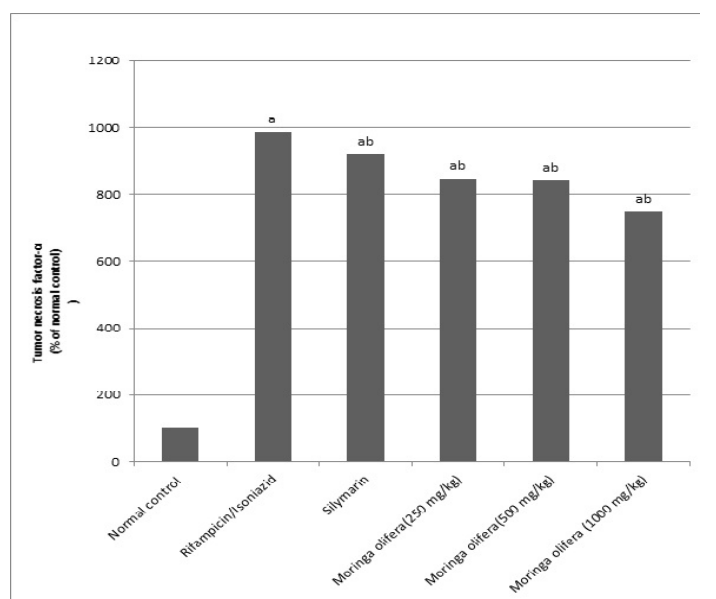

Fig. 3. Effects of Moringa oleifera extract and silymarin on Tumor necrosis factor- $\alpha$ (TNF- $\alpha$ ).

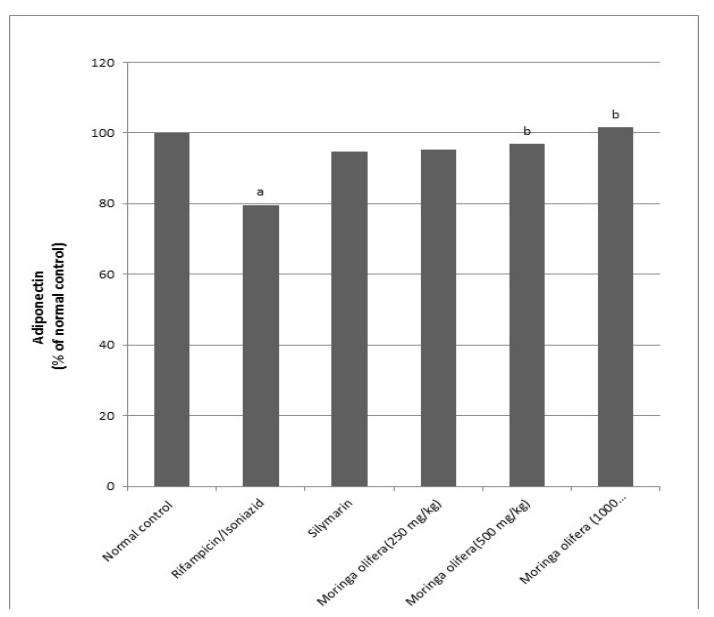

Fig. 4. Effects of Moringa oleifera extract and silymarin on Adiponectin. 


\section{Effects of Moringa oleifera extract and silymarin on liver histopathology.}

Fig.5 (A-F): Histopathology of rat liver showing (A) normal morphology with preserved hepatic architecture of the control group; (B) Large focal area of hepatocellular necrosis infiltrated with mononuclear inflammatory cells of RFP/INH $50 \mathrm{mg} / \mathrm{kg}$; (C) Vacuolar degeneration of hepatocytes associated with sporadic cell necrosis of Silymarin group; (D) Sinusoidal dilatation with congestion and few leukocytosis in group treated with Moringa oleifera $250 \mathrm{mg} /$ $\mathrm{kg}$; (E) Mild focal sinusoidal dilatation with activation of kupffer cells of Moringa oleifera $500 \mathrm{mg} / \mathrm{kg}$ group; (F) Individual cell necrosis of the periportal hepatocytes of Moringa oleifera $1000 \mathrm{mg} / \mathrm{kg}$ group.

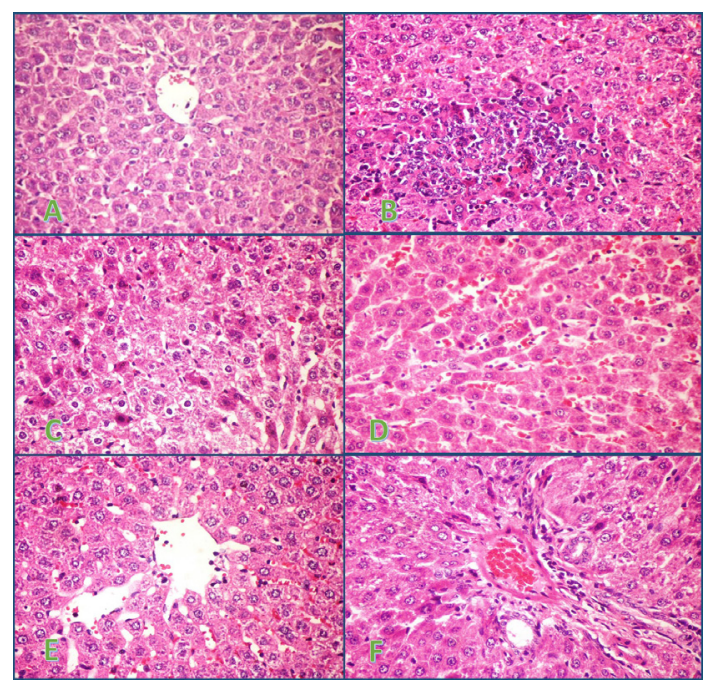

\section{Discussion}

Hepatotoxicity is one of the most important adverse drug responses associated with antituberculosis drugs that may restrict their use (36). The previous studies showed transient elevations of serum hepatocellular enzymes (AST and ALT) in approximately $10 \%$ of patients who received INH/RIF of these $1-2 \%$ patients withdrew from the treatment because of severe hepatotoxicity that ultimately led to fulminant hepatitis (37).

Our result revealed that INH/RIF administration to rats increased the levels of serum AST and ALT compared to the normal rats this was agreed by $[38,39]$. The reduction in the levels of these parameters toward the respective normal values by Moringa oleifera is an indication of the stabilization of plasma membranes as well as repair of hepatic tissue damage caused by INH/RIF [40]. The administration of silymarin decreased serum AST and ALT activities as compared to the hepatotoxic rats [26].

Serum alkaline phosphatase (ALP) level is produced by many tissues, especially bone, liver, intestine and placenta and is excreted in the bile. In the absence of bone disease and pregnancy, an elevated serum ALP levels generally reflect hepatobiliary and hepatocellular injury. The mechanism of elevated ALP levels may be due to defective hepatic excretion or by increased production of ALP by hepatic parenchymal or duct cells (41).

In addition, the current data postulated that serum level of ALP has been markedly increased by action of RIF/INH administration compared to the normal rats causing hepatic dysfunction which agrees with Qader et al, [8]. A significant decrease in the levels of serum ALP by action of Moringa oleifera compared to hepatotoxic rats revealed the improving effect of Moringa oleifera extract which agrees with Fakurazi et al., [23]. Silymarin administration showed also a marked decrease in the levels of serum ALP compared to the hepatotoxic rats. These results are in a line with Ilyas et al., [42].

Bilirubin level rises in diseases of hepatocytes, obstruction to biliary excretion into duodenum, in hemolysis and defects of hepatic uptake and conjugation of bilirubin treatment such as Gilberts disease [43] so In the present study, INH / RIF administration produced a marked rise in the levels of serum bilirubin compared to the normal rats which reflected hepatobiliary injurious effect of INH / RIF administration. This previously explained by Ravi et al. [44]. The hepatobiliary improving effect of Moringa oleifera extract achieved by its reduction to the levels of serum bilirubin. [45]. this reduction also attained by silymarin administration as reported by Fehér et al. [46].

Oxidative stress is also one of the mechanisms with a central role involved in the pathogenesis of antitubercular drugs-induced hepatotoxicity. INH and RIF induced damage may involve oxidative stress (47), lipid peroxidation (48). Current experiment exhibited oxidative stress and lipid peroxidative effect of RIF/INH administration as evidenced by increase in the 
levels of MDA compared to the normal rats. Our study conflicts with the other results proved by Lian et al. [6]. The marked decrease in the levels of MDA with administration of Moringa oleifera extract indicates that the anti-lipid peroxidation and/or adaptive nature of the systems brought about by Moringa oleifera extract acted against the damaging effects of free radicals produced by INH/RIF. The obtained results are in agreement with those of Alaaeldin[49]. The administration of silymarin also retain the normal levels of MDA protecting rats that received INH/RIF against lipid peroxidation, these result refines with the result of Rašković et al. [50].

GPx is an enzyme which catalyzes the reduction of hydroperoxides, including hydrogen peroxides, and functions to protect the cell from peroxidative damage [51].

The present investigation revealed that, INH/ RIF administration to rats provoked oxidative stress by cellular accumulation of lipid peroxides leading to a marked decline in the levels of GPx compared to the normal rats. Our findings are in the same line with earlier reported investigation of Jeyakumar et al. [52]. This oxidative stress is reduced by action of Moringa oleifera extract leading to a marked increase in the activity of GPx compared to hepatotoxic rats and helping to maintain liver cell integrity and control the increase in level of liver enzymes [53]. Moringa oleifera extract downregulate cytochrome P450 isoforms (CYP1A2 and CYP2B) [54].

In current study, silymarin administration elevated the activity of GPx compared to the hepatotoxic rats, similar to the study previously mentioned by Padmanabhan and Jangle [55].

Tumor necrosis factor alpha (TNF- $\alpha$ ) has an important role in liver inflammation and fibrosis, it activated NF-KB that becomes the driving force of inflammation. It activates the major fibrogenic molecule transforming growth factor $\beta$ (TGF- $\beta$ ), and stimulates the survival and production of activated myofibroblasts through differentiation of hepatic stellate cells (HSCs) [56].

In the present study, the increment of the levels of TNF- $\alpha$ content by INH/RIF administration indicates that INH/RIF could induce a liver inflammation in the rats. Our study agrees with Mahmoud [57]. The hepatoprotective effect of Moringa oleifera against liver inflammation is attained by its reduction of the liver content of TNF- $\alpha$ and this was agreed with Mahajan et al. [58]. The same action also happened with administration of silymarin that decreased TNF- $\alpha$ liver content, these results agree with Song et al. [59].

Egypt. J. Vet. Sci. Vol. 49. No, 1 (2018)
Adiponectin has biological significance in liver fibrosis (60). It also suppresses the proleiferation and migration of hepatic satellate cell by binding to it by adiporeceptor 2 and/or suppresses TNF- $\alpha$ mRNA expression. In addition, TNF- $\alpha$ dose dependently suppresses the gene expression and secretion of adiponectin in adipocyte so lack of adiponectin accelerates liver fibrosis [61]. In the present study, for the first time results show the relation between RIF/INH and adiponectin liver content, RIF/INH administration to rats decreased the levels of adiponectin liver content compared to the normal rats, which indicating that RIF/INH could induce liver damage in the rats. The elevation of this parameter by the action of Moringa oleifera extract implies its hepatoprotective role. silymarin administration also elevated the levels of adiponectin.

Histopathological examinationalso confirmed our laboratory findings where RIF/INH administration to rats showing diffuse hepatocellular steatosis, multifocal sinusoidal dilatation with congestion and leukocytosis, large focal area of hepatocellular necrosis infiltrated with mononuclear inflammatory cells, minute focal area of hepatocellular necrosis infiltrated with mononuclear inflammatory cells associated with abundant apoptosis and intense infiltration of portal triads with mononuclear inflammatory cells associated with individual necrosis of periportal hepatocytes.our finding is in the same line with Qader et al. [8], Ravi et al. [45] and Lian et al. [6]. Morever, Moringa oleifera extract administered to rats histopathological figure revealed individual cell necrosis of the periportal hepatocytes in histopathological examination experiment result in the same boat with Saalu et al. [54] and Sharifudin et al. [62]. silymarin has a minimal reduction in the severity of the liver damage as shown vacuolar degeneration of hepatocytes associated with sporadic cell necrosis. Our result supported by Shaarawy et al. [26]. It is concluded that Moringa olifera might be considered as adjuvant drug in treatment of liver disorder and or as hepatoprotective therapy with antitubercular drugs.

\section{$\underline{\text { References }}$}

1. Yu, C.H., Xu, C.F., Ye, H., Li, L. and Li, Y.M.: Early mortality of alcoholic hepatitis: A review of data from placebo controlled clinical trials. World $J$. Gastroentrol., 16, 2435-2439. (2010)

2. Mohamed Saleem, T.S., Madhusudahana Chetty, C., Ramakanath, S., Rajan, V.S.T., Mahesh Kumar, K. and Gauthaman, K. (2010) Hepatoprotective herbs-A Review. Int. J. Res. Pharm. Sci., 1(1),1-5. 
3. Mohan, H. (2010) Text Book of Pathology, 6th Ed, Jaypee Brothers, New Delhi,

4. Tasduq, S.A., Peerzada, K., Koul, S., Bhat, R. and Johri, R.K. (2005) Biochemical manifestations of anti-tuberculosis drugs induced hepatotoxicity and the effect of silymarin. Hepatol Res 31,132-135.

5. Hussain, Z., Kar, P. and Husain, S.A. (2003) Antituberculosis drug-induced hepatitis: risk factors, prevention and management. Indian J. Exp. Biol. , 41(11),1226-32.

6. Lian, Y., Zhao, J., Xu, P., Wang, Y., Zhao, J. et al. (2013) Protective Effects of Metallothionein on Isoniazid and Rifampicin-Induced Hepatotoxicity in Mice. PLoS ONE 8(8), e72058. doi:10.1371/ journal.pone.0072058.

7. Santhosh, S., Sini, T.K., Anandan, R. and Mathew PT. (2007) Hepatoprotective activity of chitosan against isoniazid and rifampicin-induced toxicity in experimental rats. Eur. J. Pharmacol., 572, 69-73.

8. Qader, G.I., Aziz, R.S., Ahmed, Z.A., Abdullah, Z.F. and Hussain, S.A. (2014) Protective Effects of Quercetin against Isoniazid and Rifampicin Induced Hepatotoxicity in Rats. American Journal of Pharmacological Sciences, 2(3) 56-60.

9. Shanker, G., Syversen, T., Aschner, J.L. and Aschner, M. (2005) Modulatory effect of glutathione status and antioxidants on methylmercury-induced free radical formation in primary cultures of cerebral astrocytes. Brain Res. Mol. Brain Res., 137, 11-22.

10. Moschen, A.R., Wieser, V. and Tilg, H. (2012) Adiponectin: Key Player in the Adipose TissueLiver Crosstalk. Current Medicinal Chemistry, 19(32), 5467-5473.

11. Berg, A.H., Combs, T.P. and Scherer, P.E. (2002) ACRP30/adiponectin: an adipokine regulating glucose and lipid metabolism. Trends Endocrinol Metab., 13, 84-89.

12. Xu, A., Wang, Y., Keshaw, H., Xu, L.Y., Lam, K.S.L. and Cooper, G.J.S. (2003) The fat-derived hormone adiponectin alleviates alcoholic and nonalcoholic fatty liver diseases in mice. J. Clin. Invest. 112, 91-100.

13. Wolf, A.M., Wolf, D., Avila, M.A., Moschen, A.R., Berasain, C., Enrich, B., Rumpold, H. and Tilg, H. (2006) Up-regulation of the anti-inflammatory adipokine adiponectin in acute liver failure in mice. Journal of Hepatology, 44(3), 537-543.

14. Chatterjee T. K., (2000) "Medicinal Plants with Hepatoprotective Properties in Herbal Options," 3rd ed., Books and Allied (P) Ltd., Calcutta, 135.

15. Subash, K.R., Ramesh, K.S., Charian, B.V., Britto, F., Rao, N.J. and Vijaykumar, S. (2011) Study of hepatoprotective activity of Solanum nigrum and Cichorium intybus. International Journal of Pharmacology, 7 (4), 504-509.

16. Oliveira, J.T.A., Silveira, S.B., Vasconcelos, K.M., Cavada, B.S. and Moreira, R.A. (1999) Compositional and nutritional attributes of seeds from the multiple purpose tree Moringa oleifera Lamarck. J. Sci. Food Agric. 79, 815-820.

17. Khalafalla, M.M., Abdellatef, E., Dafalla, H.M., Nassrallah, A.A., Aboul-Enein, K.M., Lightfoot, D.A., El-Deeb, F.E. and El-Shemy, H.A. ( 2010) Active principle from Moringa oleifera Lam leaves effective against two leukemias and a hepatocarcinoma. Afr. J. Biotechnol., 9(49), 84678471.

18. Chumark, P., Khunawat, P., Sanvarinda, Y., Phornchirasilp, S., Morales, N.P., Phivthongngam, L., Ratanachamnong, P., Srisawat, S. and Pongrapeeporn, K.S. (2008) The in vitro and ex vivo antioxidant properties, hypolipidaemic and antiatherosclerotic activities of water extract of Moringa oleifera Lam Leaves. J. Ethnopharmacol., 116, 439-446.

19. Iqbal, S. and Bhanger, M.I. (2006) Effect of season and production location on antioxidant activity of Moringa oleifera leaves grown in Pakistan. J. Food Compos. Anal. 19, 544-55.

20. Faizi, S., Siddiqui, B., Saleem, R., Saddiqui, S. and Aftab, K. (1994) Isolation and structure elucidation of new nitrile and mustard oil glycosides from Moringa oleifera and their effect on blood pressure. J. Nat. Prod. 57, 1256-1261.

21. Anwar, F., Latif, S., Ashraf, M. and Gilani, A.H. (2007) Moringa oleifera: A food plant with multiple medicinal uses. Phytother. Res., 21, 17-25.

22. Atawodi, S.E., Atawodi, J.C., Idakwo, G.A., Pfundstein, B., Haubner, R., Wurtele, G., Bartsch, H. and Owen, R.W. (2010) Evaluation of the polyphenol content and antioxidant properties of methanol extracts of the leaves, stem, and root barks of Moringa oleifera Lam. J. Med. Food, 13, 710-716.

23. Fakurazi, S., Hairuszah, I. and Nanthini, U. (2008) Moringa oleifera Lam prevents acetaminophen induced liver injury through restoration of glutathione level. Food Chem. Toxicol., 46, 2611-2615.

24. Uma, N., Fakurazi, S., Hairuszah, I. (2010) Moringa oleifera enhances liver antioxidant status via elevations of antioxidant enzymes activity and counteracts paracetamol-induced hepatotoxicity. Malayas. J. Nutr., 16, 293-307.

25. Rana, S.V., Pal, R., Vaiphie, K. and Singh, K. (2006) Effect of different oral doses of isoniazid-rifampicin in rats. Mol. Cell. Biochem., 289(1-2), 39-47.

Egypt. J. Vet. Sci. Vol. 49. No, 1 (2018) 
26. Shaarawy, S.M., Tohamy, A.A., Elgendy, S.M., Abd Elmageed, Z.Y., Bahnasy, A., Mohamed, M.S. Kandil, E. and Matrougui, K. (2009) Protective Effects of Garlic and Silymarin on NDEA-Induced Rats Hepatotoxicity. Int. J. Biol. Sci., 5(6), 549557.

27. Singh, N., Verma V.K., Saxena, P. and Singh, R. (2012) Anti-Ulcer and Antioxidant Activity of Moringa oleifera (Lam) Leaves against Aspirin and Ethanol Induced Gastric Ulcer in Rats. Int. Res. J. of Pharmaceuticals, 2 (2), 46-57.

28. Reitman, S. and Frankel, S. (1957) A colorimetric method for the determination of serum glutamic oxalacetic and glutamic pyruvic transaminases. $\mathrm{Am}$ J Clin Pathol 28(1) 56-63.

29. Belfield, A. and Goldberg, D. (1971) Colorimetric determination of alkaline phosphatase activity. Enzyme; 12(5), 561-568.

30. Walters, M.I. and Gerarde, H. (1970) An ultramicromethod for the determination of conjugated and total bilirubin in serum or plasma. Microchemical Journal, 15(2), 231-243.

31. Ohkawa, H., Ohishi, N. and Yagi, K. (1979) Assay for lipid peroxides in animal tissues by thiobarbituric acid reaction. Analytical biochemistry, 95(2), 351-358.

32. Paglia, D.E. and Valentine, W.N. (1967) Studies on the quantitative and qualitative characterization of erythrocyte glutathione peroxidase. J. Lab. Clin. Med. 70, 158 - 169.

33. Pennica, D., Nedwin, G.E., Hayflick, J.S., Seeburg, P.H., Derynck, R., Palladino, M.A. et al., (1984) Human tumour necrosis factor: Precursor structure, expression and homology to lymphotoxin. Nature, 312(5996), 724-729.

34. Kojima, S., Funahashi, T., Sakamoto, T., Miyamoto, S., Soejima, H., Hokamaki, J., Kajiwara, I., Sugiyama, S., Yoshimura, M., Fujimoto, K., Miyao, Y., Suefuji, H., Kitagawa, A., Ouchi, N., Kihara, S., Matsuzawa, Y., and Ogawa, H. (2003) The variation of plasma concentrations of a novel, adipocyte derived protein, adiponectin, in patients with acute myocardial infarction. Heart, 89(6), 667.

35. Carleton, H.M., Drury, R.A.B. and Wallington, E.A. (1980) Carleton's histological technique. Journal of clinical pathology 4th edn. P. 116.

36. Bassey, E.B., Momoh, M.A., Imadiyi, S.O., Udofia, E.B., Miri, F.S. et al., (2005) The trend of pulmonary tuberculosis in patients seen at DOTS clinics in the Federal Capital Territory, Abuja, Nigeria. Public Health, 119, 405-408.

37. Ali, J. (1996) Hepatotoxic effects of tuberculosis therapy. A practical approach to a tricky management problem. Postgrad Med, 99, 217-220, 230-236.

38. Gond, N. Y. and Khadabadi, S. S. (2008) Hepatoprotective Activity of Ficus carica Leaf Extract on Rifampicin-Induced Hepatic Damage in Rats. Indian J Pharm Sci., 70(3), 364-366.

39. Issabeagloo, E. and Taghizadieh, M. (2012): Hepatomodulatory Action of Camellia sinensis Aqueous Extract Against Isoniazid-Rifampicin Combination Induced Oxidative Stress in Rat. Advances in Bioresearch, 3 (3), 18-27.

40. Singh, D., Arya, P.V., Aggarwal, V.P. and Gupta, R.S. (2014) Evaluation of Antioxidant and Hepatoprotective Activities of Moringa oleifera Lam. Leaves in Carbon Tetrachloride-Intoxicated Rats Antioxidants, 3(3), 569-591.

41. Swaroop, T.V.S.S. and Shivalinge, G.K.P. (2012) Hepatotoxicity Mechanisms and its Biomarkers. International Journal of Pharmaceutical And Chemical Sciences, 1 (2), 675-682.

42. Ilyas, N., Sadiq, M. and Jehangir, A. (2011) Hepatoprotective effect of garlic (Allium sativum) and milk thistle (silymarin) in isoniazid induced hepatotoxicity in rats. Biomedica, 27, $166-170$.

43. Harshmohan, (2002) The liver, biliary tract and exocrine pancreas. In: Text book of pathology, 4th Ed, Jaypee Brothers Medical Publishers (P) Ltd. New Delhi., 22-4 and 569-630.

44. Ravi, V., Patel, S.S., Verma, N.K., Dutta, D. and Saleem, T.S.M. (2010) Hepatoprotective Activity of Bombax ceiba Linn against Isoniazid and Rifampicin-induced Toxicity in Experimental Rats. International Journal of Applied Research in Natural Products, 3 (3),19-26.

45. Ugwu, O.P.C., Nwodo, O.F.C., Joshua, P.E., Odo, C.E., Ossai, E.C. and Aburbakar, B. (2013) Ameliorative effects of ethanol leaf extract of Moringa oleifera on the liver and kidney markers of malaria infected mice. J. LifeSc. Bt \& Pharm. Res., 2(2), 43-52.

46. Fehér, J., Deák, G., Müzes, G., Láng, I., Niederland, V., Nékám, K., Kárteszi, M. and Hetilap, O. (1989) Liver-protective action of silymarin therapy in chronic alcoholic liver diseases. Europe PubMed Central, 130(51), 2723-2727.

47. Attri, S., Rana, S.V., Vaiphei, K., Sodhi, C.P., Katyal, R., Goel, R. C., Nain, C. K., Singh, K. (2000) Isoniazid and rifampicin-induced oxidative hepatic injury--protection by $\mathrm{N}$-acetylcysteine. Hum Exp Toxicol, 19, 517-22.

48. Richards, V.E., Chau, B., White, M.R. and McQueen, C.A. (2004) Hepatic gene expression and lipid

Egypt. J. Vet. Sci. Vol. 49. No, 1 (2018) 
homeostasis in C57BL/6 mice exposed to hydrazine or acetylhydrazine. Toxicol Sci, 82, 318-32.

49. Alaaeldin, A.H. (2007) Curcuma longa,Glycyrrhiza globra and Moringa olifera Ameliorate Diclofenacinduced hepatotoxicity. American Journal of pharmacology and toxicology, 2(2), 80-88.

50. Rašković, A., Stilinović, N., Kolarović, J., Vasović, V., Vukmirović, S. and Mikov, M. (2011) The Protective Effects of Silymarin against DoxorubicinInduced Cardiotoxicity and Hepatotoxicity in Rats. Molecules, 16, 8601-8613.

51. Halliwell B J. (1995) Reactive oxygen species and the central nervous system. Neurochem, 59,160923.

52. Jeyakumar, R., Rajesh, R., Meena, B., Rajaprabhu, D., Ganesan, B., Buddhan, S. and Anandan, R. (2008) Antihepatotoxic effect of Picrorhiza kurroa on mitochondrial defense system in antitubercular drugs (isoniazid and rifampicin)-induced hepatitis in rats. Journal of Medicinal Plants Research, 2(1), 017-019.

53. Saalu, L.C., Ogunlade, B., Ajayi, G.O., Oyewopo, A.O., Akunna, G.G. and Ogunmodede, O.S. (2012) The hepato-protective potentials of Moringa oleifera leaf extract on alcohol-induced hepatotoxicity in wistar rat. Am. J. Biotechnol. Mol. Sci., 2(1), 6-14.

54. Eshak, M. G., Hassanane, M. M., Farag, I.M., Shaffie, N.M. and Abdalla, A. M. (2015): Evaluation of Protective and Therapeutic Role of Moringa oleifera leaf extract on CCL4-induced genotoxicity, hemotoxicity and hepatotoxicity in rats. Int. J. PharmTech Res., 7 (2), 392-415.

55. Padmanabhan, P. and Jangle, S.N. (2013) Hepatoprtotective activity of herbal preparation (hp-4) against paracetamol induced hepatotoxicity in mice. International Journal of Basic and Applied Medical Sciences, 3 (3),49-59.

56. Elsharkawy, A.M. and Mann, D.A. (2007) Nuclear factor-kappaB and the hepatic inflammationfibrosis-cancer axis. Hepatology, 46(2), 590-597.

57 Mahmoud, A.M., Morsy, B.M., Abdel-Hady, D.S. and Samy, R.M. (2015) Prunus armeniaca Leaves Extract Protects against Isoniazid and Rifampicin Induced Nephrotoxicity through Modulation of Oxidative stress and Inflammation. Int. J. Food. Nutr. Sci., 2(4),1-6.

58. Mahajan, S.G., Mali, R.G. and Mehta, A.A. (2007) Protective Effect of Ethanolic Extract of Seeds of Moringa oleifera Lam. against Inflammation Associated with Development of Arthritis in Rats. Journal of Immunotoxicology, 4(1), 39-47.
59. Song, Z., Deaciuc, I., Song, M., Lee, D.Y.-W., Liu, Y. Ji, X. and McClain, C. (2006) Silymarin Protects Against Acute Ethanol-Induced Hepatotoxicity in Mice. Alcohol Clin Exp Res., 30(3), 407-413.

60. Kamada, Y., Tamura, S., Kiso, S., Matsumoto, H., Saji, Y., Yoshida, Y., Fukui, K., Maeda, N., Nishizawa, H., Nagaretani, H., Okamoto, Y., Kihara, S., Miyagawa, J., Shinomura, Y., Funahashi, T. and Matsuzawa Y. (2003) Enhanced carbon tetrachloride induced liver fibrosis in mice lacking adiponectin. Gastroentrology, 125,1796-1807.

61. Tang, M., Potter, J. and Mezey, E.( 2002) leptin enhance the effect of transforming growth factor beta in increasing type I collagen formation. Biochem Biophys Res Commun,297, 906-911.

62. Sharifudin, S.A.; Fakurazi, S, Hidayat, M.T; Hairuszah, I.; Moklas, M. A. M. \& Arulselvan, P. (2013) Therapeutic potential of Moringa oleifera extracts against acetaminophen-induced hepatotoxicity in rats. Pharmaceutical Biology, 51 (3), 279-288.

(Received 31/12/2017; accepted 30/1/2018) 


\section{التأثير الواقى لمستخلص المورينجا اوليفيرا من تسمح الكبا بمادتى ايزونيازايد و الريفامبيسين : وتتضمن الاديبونكتين وعامل الفا لاحداث التنقرز عبير احمد سلامة" و محمد فايد عبدالحميد" ; طه عبدالفتاح عطيه** وسهام عبدالستار البطران"واسماعيل

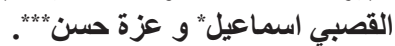

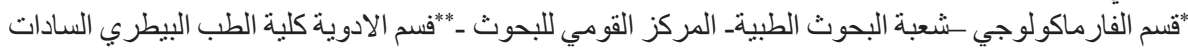

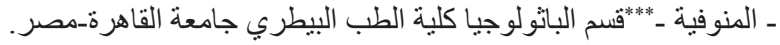

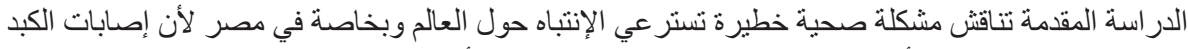

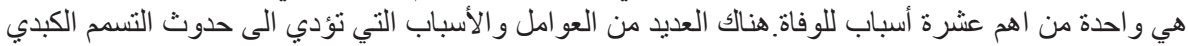

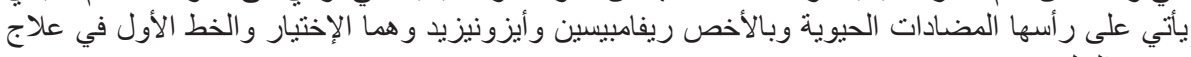
مرض السل.

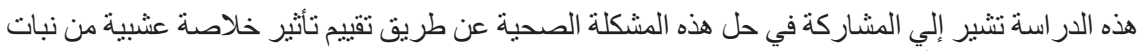

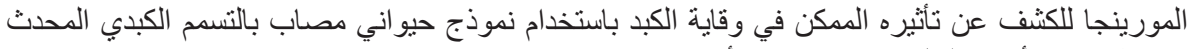

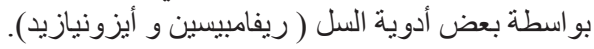

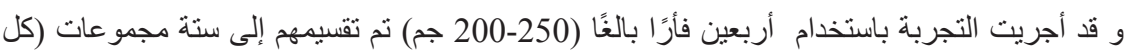

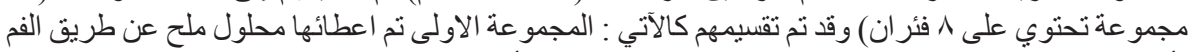

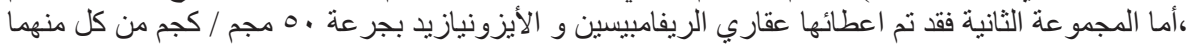

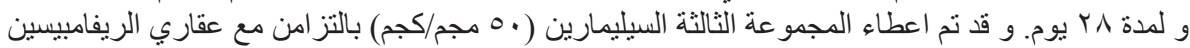

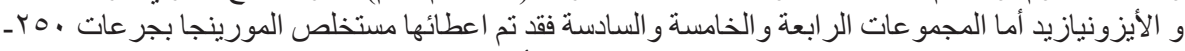

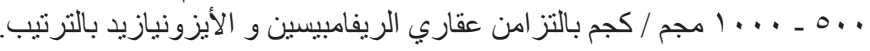

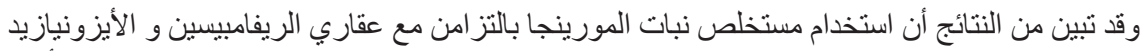

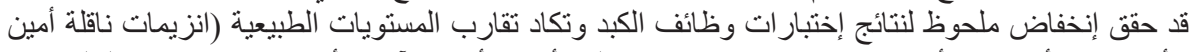

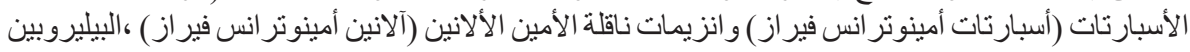

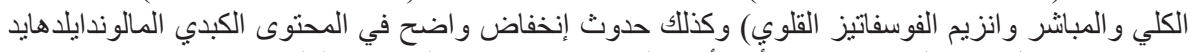

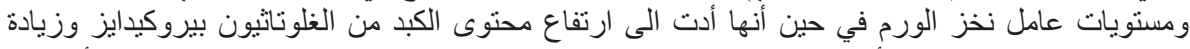

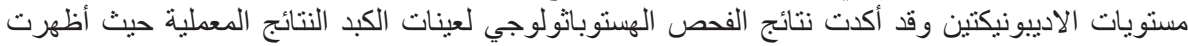
وجود خلايا كبدية سليمة و انخفاض في حدة اصنابة الخلايا الكبدية

ونستخلص من ذللك أن مستخلص المورينجا يعتبر كدو اء مساعد لتحسين حالة الكبد في حالات الاعتلال

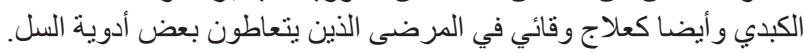

